\title{
SPEAKING SKILL IN USING COMMUNITY \\ LANGUAGE LEARNING (CLL)
}

\author{
Gunaldi Masbiran \\ Academy of Foreign Language Persada Bunda Pekanbaru, Indonesia \\ gunaldim81@gmail.com
}

Andi Fauzi

Sekolah Tinggi Pariwisata Pekanbaru, Indonesia

andi@gmail.com

\begin{abstract}
The researcher applied Community Language Learning (CLL) in teaching speaking skill. The purpose of this research was to identify the effect of using Community Language Learning (CLL) Method towards speaking skill students who received the class instruction by using CLL than students who do not receive method at the second semester students of ABA Persada Bunda in Pekanbaru. The design of the research was experimental design with the total number of population are 25 students from the second semester students of ABA Persada Bunda in Pekanbaru. Instrument in this research was an oral test speaking by report. Data were analyzed using ttest. The result of the test showed that the average score of students' pre test was 68,50 and then the average of students post test was 74,58. The results of this research found that the alternative hypothesis was accepted and rejected a hypothesis null. It can be seen from the t-test (0.000) significant at the level of 0.05 . The result of $\mathrm{N}$-Gain of experimental class was 0,31 . It meant that the significant of strategy that used in experimental class was Middle because the average of N-Gain was 0.31. From the above explanation, the researcher concluded that Community Language Learning (CLL) Method effective for teaching speaking skill at the second semester students of ABA Persada Bunda in Pekanbaru.
\end{abstract}

Keywords: Community Language Learning (CLL) Method, Speaking Skill

\section{Introduction}

English learning process in Academy of Forign Language (ABA) was conducted in different day for each skill based on syllabus. But, every skills were always connected each other. It could be seen for the material they learn. They learned speaking in 3 (credit semester) once a week; especially speaking subject in this case Speaking I subject.

Based on Syllabus of Academy particularly in speaking skill, students targeted to be able speak well in all aspects of speaking. One of competences focuses on speaking, students are demanded to understand the meaning of the conversation transactional and interpersonal. Firstly, 
students are able using a variety of short simple spoken language accurately fluently and acceptable to interact in the context of everyday life involving respond to greeting, farewell, thanks, and apologies, can also ask and respond about self-introduction. Secondly, the students are able understanding the meaning of descriptive person to interact in the context of life.

Related to the premise and exlpanation above, researcher conducted an experimental research entitled "Speaking Skill in Using Community Language Learning (CLL) at the Second Semester Students of ABA Persada Bunda in Pekanbaru.

Based on what has been discussed in the background of the research above, can be identified in two aspects. Most of students's accent had to do the exercise daily. Some students had to practice their English in English class. The purpose of the research is to investigate the effectiveness of using CLL method towards speaking skill at the second semester students of ABA Persada Bunda in Pekanbaru.

\section{Speaking Skill}

Chaney in kayi (2006) defines that speaking is the process of building and sharing meaning through the use of verbal and non-verbal symbols, in a variety of context. It means that the goal of teaching speaking should improve students' communicative skills, because, only in that way, students can express themselves and learn how to follow the social and cultural rules appropriate in each communicative circumstance.

Components in speaking are needed to know well in measuring students' ability on speaking skill. Furthemore, knowledge and self confidence and way in delivering are the basic elements of an effective speech. Therefore, there were some experts who have several arguments about the speaking components.

In first argument, Syakur in Mora (2010) speaking is a complex skill because at least it is concerned with components consist of four components: grammar, vocabulary, pronounciation, and fluency. Furthemore, Nakamura in Trong (2012) the scoring scale in components of speaking assessment based on: coherence, content, grammar, structure and language used: spelling, vocabulary. It more completely Hughes (2005) in Fajriyanti (2009), he argues that component in speaking that is different from statement above. $\mathrm{He}$ states that there are five components of speaking that consist of: accent, grammar, vocabulary, fluency, and comprehension. Hughes adds comprehension as include in speaking components that is an important components in speaking. Applying comprehension is expected to enlarge students' knowledge about speaking.

And the conclusion, the researcher will use components in speaking by Hughes that consist of: accent, grammar, vocabulary, fluency, and comprehension. The first, accent that is include how the learners can speak by using good pronounciation. The learners mispronounciation that will effect on unclear the meaning when deliver the message. Secondly, grammar that is include structure in sentence pattern. Thirdly, vocabulary as a fundamental when the learners speak in using English. Fourthly, Fluency that can make effective in catch the meaning clearly. And the last, comprehension that can enlarge the learners knowledge about speaking skill and improve their speaking skill. All of components will be applied to assess the students during having this research. 


\section{Community Language Learning (CLL) Method}

The Community Language Learning is the method which are use by the teachers to consider their students as 'whole persons' (Charles A. Currant, 1951 in Larsen -Freeman). Whole persons means that teachers consider not only their students intellect, but also have some understanding of the relationship among students feelings, physical reactions, instinctive protective reactions, and desire to learn. The teachers who use this method want their students to learn how to use the target language communicatively. In the class, the teachers become counselor. It is doesn't mean the teachers trained their students in psychology. In this method, the teachers use tape-recorded, transcription, reflection on experience, reflective listening, human computer, and small group tasks to see our 'whole persons'.

According to Curran (1972), types of learning and teaching activity community language learning involves learning task and activities take place in learning and teaching process as follows:

1) Translation. Learners from a small circle. A learner whisper a message or meaning he or she want to express, the teacher translates it into the target language, and the learner repeats the teacher's translation.

2) Group work. Learners may engage in various group tasks, such as small group discussion of a topic, preparing a conversation, preparing a summary of a topic for presentation to other group. Preparing a story that will be presented to the teacher and the rest of the class..
3) Analysis. Students analyze and study transcriptions of target language sentence in order to focus on particular lexical usage or on the application of particular grammar rules.

4) Reflection and observation. Learners reflect and report on their experience of the class, as a class or in groups.

5) Listening. Students listen to a monologue by the teacher involving elements they might have elicited or over hear in class interactions.

6) Free conversation. Students engage in free conversation with the teacher or with other learners.

Materials developed by the teacher as the course develops, although these generally consist of little more than summaries on the blackboard or overhead projector of some of the linguistic features of conversations generated by students. Conversations may also be transcribed and distributed for study and analysis, and learners may work in groups to produce their own materials, such as scripts for dialogues and mini-dramas. (La Forge, 1983 in Koba)

Generally the observer will see a circle of learners all facing one another. The teacher might then form the class into facing lines for three-minute pair conversations. These are seen as equivalent to the brief wrestling sessions by which judo students practice. Following this the class might be reformed into small groups in which a single topic, chosen by the class or the group, is discussed. The summary of the group discussion may be presented to another group, who in turn try to repeat or paraphrase the summary back to the original group. 
In an intermediate or advanced class a teacher may encourage groups to prepare a paper drama for presentation to the rest of the class. A paper drama group prepares a story that is told or shown to the counselor. The counselor provides or corrects target language statements and suggests improvements to the story sequence. Students are then given materials with which they prepare large picture cards to accompany their story. After practicing the story dialogue and preparing the accompanying pictures, each group presents its paper drama to the rest of the class. The students accompany their story with music, puppets, and drums as well as with their pictures (La Forge 1983: 81-2)

Finally, the teacher asks learners to reflect on the language class, as a class or in groups. Reflection provides the basis for discussion of contracts (written or oral contracts that learners and teachers have agreed upon and that specify what they agree to accomplish within the course), personal interaction, feelings toward the knower and learner, and the sense of progress and frustration.

\section{Method}

The research was experimental research. An experimental research is the traditional approach to conducting quantitative research (Creswell 2005:282). In an experiment, test an idea (or practice or procedure) to determine whether it influences an outcome or dependent variable. Then when the independent variable influenced the dependent variable, we can say the independent independent variable "caused" or "probably caused" the independent variable. Since experiment was controlled, they are the best of the quantitative design to use to establish probable cause and effect.
In this type of experimental research, researcher chose Quasi experimental (pre and post-test) Between-Group Research. The researcher is going to find in educational research is Quasi experiment in Between-Group which most frequently used designs in education are those were the researcher compares two or more groups (Creswell 2005:295). And the Quasi experimental research include assignment, but no random assignment of participants to groups. The researcher assigned intact groups of the experimental and control treatments, research a pre-test to both groups, conduct experimental treatment activities with the experimental group only, and then research a post-test to asses the different between the two groups.

After collecting the data, researcher obtain the results tabulated values of students between treatment class by using Communnity Language Learning (CLL) method and control class by ordinary method in speaking.

After that, researcher statistically analyzed it by using T-test when the data was normal and homogenous and use U Mann-Whitney if the data is not normal or not homogenous. The special data that would be got is used to see the improvement student's speaking ability is the result data from pre-test and posttest score. The data would be analyzed to know the result of the test. The result data then is calculated the average of the score. It would be calculating $\mathrm{N}$ Gain between pre-test and post-test in experimental class. N-Gain is used to know the effect size the treatment that was given to experimental class.

\section{Findings}

This chapter presents the result of the research that includes the findings and discussion. The data presentation of this study includes the analysis of the 
pre-test and post-test between experimental class and control class. These are done to answer the formulation of the research, "Is there any significant effect of using Community Language Learning Method towards Speaking Skill at the second semester students of ABA Persada Bunda in Pekanbaru?" In this part, the formulation is answered based on the data gotten from pre-test and post-test by using speaking test. The result of this research could be seen in the following discussion with analyzed by using SPSS 16.00 for windows.

\section{a. Post-test}

Post-test conducted after the students had received the treatment in several meetings. The post-tes was done to measure speaking ability of the students after having the treatment. Based on the data that had been collected in post-test, the researcher was getting score both experiment class and control class showed the maximum score, minimum score, and average score of post-test on the experiment class and the control class. The minimum score of experiment class was 57.00, while the control class was 53.00. The maximum score on experimentaal class was 90.00, it was higher than control class was having 78.00. Moreover, the average of two classes was different. The average of post-test on the experimental class was 74.58 and the control class was 65.64 .

\section{The Result Posttest Score of Scoring Rubric Speaking Skill Experimental Class and Control Class}

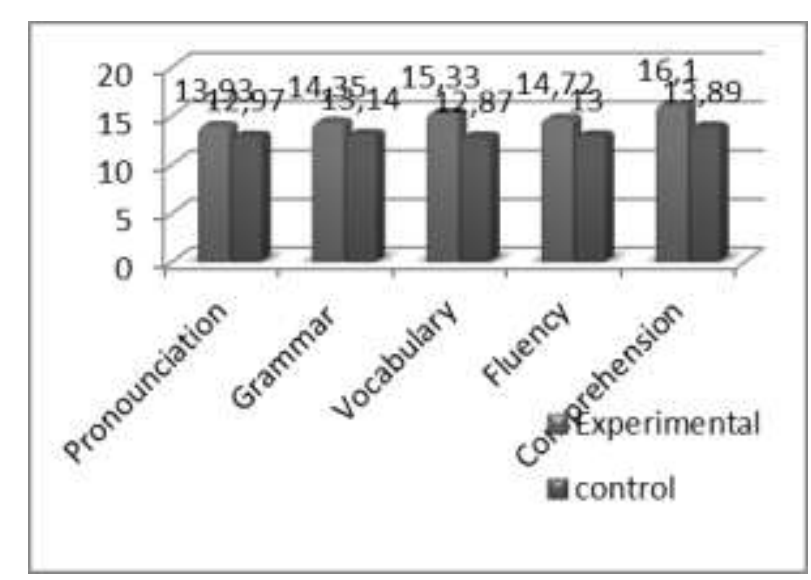

From diagram 4.3 above, it conclude that the students' scores in pronounciation in experimental class was 13.93 and control class was got 12.97, the grammar scores of experimental class was 14.35 and control class got 13.14, the vocabulary scores of experimental class was 15.33 and control class was 12.87, the fluency sores of experimental class was 14.72 and control class was 13.00 , the comprehension scores of experimental class was 16.10 and control class was 13.89 .

The normality test of post-test on experimental class and control class had normal distribution. It was seen from the score in column Asymp.Sig.(2tailed) of experiment class was 0.916 with significant level $(\alpha=0.05)$. So, Asymp.Sig.(2-tailed) $0.916>0.05$, it means that distribution the data of experiment class was normal. Moreover, control class was got Asymp.Sig.(2-tailed) 0.802> significant 
level $(\alpha=0.05), \quad$ it meant that distribution the data of control class was normal because Asymp.Sig. (2-tailed) $0.802>0.05$.

While, the value of Based on trimmed mean was 0.595 with significant level 0.05 . It meant that value of Based on trimmed mean was higher than significant level. It could be concluded post-test data on experimental class and control class were homogeneous variance when value of based on trimmed mean $0.595>0.05$. It meant that post-test data both the classes were Homogenous.

T-test of post-test on experimental class and control class were differ significant because value of Asymp.Sig. (2-tailed) $<$ significant level $(\alpha=0.05)$. The value of Asymp.Sig. (2-tailed) was $0.000<0.05$. It meant that both of two classes were differ significant. It can be concluded that there was a significant effect of Community Language Learning (CLL) Method in teaching speaking at the second semester students of ABA Persada Bunda in Pekanbaru.

The average N-Gain was 0.33 . Based on the criteria of achievement N-Gain score on experimental class was got score $0.3<\mathrm{g}<0.7$ or $0.3<0.31<0.7$. It meant that the significant of Community Language Learning (CLL) Method in teaching speaking that used on experimental class was middle category.

\section{Discussion}

After that, students' speaking skill test result from pre test score to post test, students' grammar scores were various. The students' grammar score on post test; there were often make grammar mistake so that influence the meaning, but sometimes also it did not influence the meaning. It was caused in learning process they was sharing with their friend (part of CLL Method). It was influenced by their comprehension in grammar well. They could used the sentence suitable with tense were needed.

Then, students' speaking skill test result from pre test score to post test, students' vocabulary scores were various. The students' vocabulary score on post test; students often used unappropriate vocabulary so the dialogue become limited because of limited vocabulary, but it was higher than pretest score. It was caused in learning process when the teacher translates some words into the target language, they was repeats the teacher's translation sharing with their friend (part of CLL Method). It was influenced their vocabulary.

Furthermore, Students' speaking skill test result from pre test score to post test, students' comprehension scores were various. The students' comprehension score on post test; most comprehend in what she/he said although there were some repeating.

\section{Example:}

Student 11 said,

"ai won tu introjus samwan, ai won tu introjuis mai mader. Mai moder..."

Student 23 said,

"ai won deskrip abot..ai won tu descriptif mai mom...aim rilli... i'm rillly rilly lop mai mom...dst"

From above, it showed most of students' comprehend in all, although there was repeating in certain part. It was caused in learning process students' have positive response with the researcher explanation and the students' active participation was high (part of CLL Method). So that their comprehension about the topic was caused by their diligent. 
As clarified previously, there was positive effect of using Community Language Learning (CLL) Method towards speaking skill at the second semester students of ABA Persada Bunda in Pekanbaru where this method helped the students spoke preferences well. By using this method could optimize the used of all the potential of the students and also kept the attention of students to remain focused on the learning process. This method aims to improve student learning activities in the classroom, such as asking, answering or disprove and automatically can improve their speaking ability. It supported by (Charles A. Currant, 1951 in Larsen Freeman) Community Language Learning is the method which are use by the teachers to consider their students as 'whole persons'. Whole persons means that teachers consider not only their students intellect, but also have some understanding of the relationship among students feelings, physical reactions, instinctive protective reactions, and desire to learn. The teachers who use this method want their students to learn how to use the target language communicatively.

The research also related to the related findings that ever done before by Damayanti (2012). Community Language Learning (CLL) Method could help to development students' speaking skill. This method could build a relationship among students in a trusting relationship. It supported by Monalisa (2012) that Community Language Learning (CLL) Method be able the students could speak more in English, their also have positive response with the researcher explanation and the students' active participation was high.

\section{Conclusions}

Based on the findings and discussion, The result of this research can conclude that the Community Language Learning (CLL) Method is effective for teaching speaking skill at the second semester students of ABA Persada Bunda in Pekanbaru.

\section{References}

Agnisa, Husnia Tsalisa. 2012. The Speaking Ability of the Eleventh Grade Students of MAN 1 Kudus in Academic Year 2011/2012 Taught by Using Community Language Learning (CLL) Method. Retrieved on April.2014 http://eprints.umk.ac.id/view/subj ects/PE.html

Creswell, J. W. 2005. Educational Research. New Jersey. Person Education International

Curran, Charles. 1972. Community Language Learning. http://www2.vobs.at/ludescher/Alt ernative\%20methods/Community \%20Language\%20Learning.doc.

Damayanti, Imai. 2012. The Influence of Using Community Language Learning (CLL) Method on Improving Students' Speaking Skill at the Fifth Grade of Smart English Cource in Kuningan. Retrieved on April.2014. http://elib.iaincirebon.ac.id/simpu s/index.php? $\mathrm{p}=$ show_detail\&id=2 $\underline{1491}$

Fajriyanti, desrina. 2009. Using Community Language Learning Method in Improving Students' Speaking Skill. Unpublished thesis.

Kayi, Hayriye. 2006. Teaching Speaking: Activities to Promote Speaking in a Second Language. 
University of Neveada (Nevada, USA), Vol. XII, Retrieved July 29, 2014 at http://iteslj.org/ Articles/Kayi-Teaching

Speaking.html

Koba, Naomi. 2000. Using the Community Language Learning Approach to Cope with Language Anxiety. Retrieved from: http://iteslj.org/Articles/KobaCLL.html

Monalisa. 2012. The Use of Community Language Learning Method to Improve Speaking Ability of The First Year Student at Islamic Vocational High School of Batu. Retrieved on April.2014.

http://www.infodiknas.com/the-use-ofcommunity-language-learningmethod-to-improve-speakingability-of-the-first-year-studentsat-islamic-vocational-high-schoolof-batu.html
Mora, Minda. 2010. Teaching Speaking. Retrieved from http://www.scribd.com/doc/29712 212/27235175-TeachingSpeaking-in-a-Classroom

Trong, Luu. 2012. Teaching and Assessing Speaking Performance Through Analytic Scoring Approach.

Retrieved from: http://jalt.org/pansig/2004/HTML/ Nakamura.html

Yuliana .2010. Teaching Speaking using Community Language Learning Method at the First Grade Students of SMAN 1 Pedes. Retrieved on April.2014.

http://publikasi.stkipsiliwangi.ac.id/files /2012/09/10220619-heni-y-.pdf epository.usu.ac.id/bitstream/1234 56789/24558/2/reference.pdf 